J. AMER. SOC. HorT. SCI. 118(1):17-22. 1993.

\title{
Comparison of Plant Establishment Method, Transplant, or Direct Seeding on Growth and Yield of Bell Pepper
}

\author{
Daniel I. Leskovar ${ }^{1}$ and Daniel J. Cantliffe \\ Vegetable Crops Department, Institute of Food and Agricultural Sciences, University of Florida, \\ Gainesville, FL 32611
}

Additional index words. Capsicum annum, allometry, irrigation, priming, root growth, shoot growth

\begin{abstract}
Transplants produced with overhead or subirrigation and plants from direct seeding using primed or nontreated 'Jupiter' bell pepper (Capsicum annuum L.) seeds were evaluated for growth and yield in the field for 3 years. Early in development, overhead-irrigated (01) transplants had more basal root elongation than subirrigated (SI) transplants; however, root growth differences caused by irrigation systems in the greenhouse were minimized during late ontogeny in the field. Basal, lateral, and taproot dry weights accounted for $81 \%$, $15 \%$, and $4 \%$ of the total for transplants and $25 \%, 57 \%$, and $18 \%$ of the total for direct-seeded plants. Direct-seeded plants maintained a more-balanced root, stem, leaf, and fruit dry matter partitioning than transplants, which allocated more dry weight (per unit of root growth) to stems, leaves, and fruits. Over all seasons, transplants exhibited significantly higher and earlier yields than direct-seeded pepper plants, and total yields were similar between SI and OI transplants and between primed and nontreated seeds.
\end{abstract}

Bell pepper is established in the field by direct seeding or from containerized transplants generally grown in multicellular trays in greenhouses. Direct seeding can result in slow, variable, and reduced plant stands when extreme high or low temperatures, water stress, heavy rains, or the presence of soil-borne pests and diseases occur at the time of seeding (Heydecker and Coolbear, 1977). Plants established by transplanting are more uniform, can tolerate or escape early environmental/biological stresses, and can achieve earlier maturity than direct-seeded plants (Liptay et al., 1982). The choice of a planting system depends on the economics of plant establishment, plant performance after establishment, and the value of the subsequent yield.

Direct-seeded plants develop a strong taproot (Weaver and Bruner, 1927), while transplants may develop a distinctive root system caused by the early modification of the taproot in the containers (McKee, 1981) and the subsequent development of lateral and basal roots (Leskovar et al., 1989; Stoffella et al., 1988). Early root morphology and development may ultimately affect shoot and fruit development and consequently crop production (Thomas et al., 1982). Containerized pepper transplants grown with polyethylene mulch and sprinkler irrigation exhibited a more-uniform root growth and had more dry matter partitioned to fruits than direct-seeded plants (Leskovar et al., 1990a).

The objective of this study was to investigate how methods of plant establishment, using either transplants produced with overhead and subirrigation systems or direct seeding using primed and nontreated seeds, influences early growth and yield of bell peppers.

\section{Materials and Methods}

Plant material. 'Jupiter' pepper transplants grown with overhead- and subirrigation and primed and nontreated seeds were planted in the field in Spring 1988, 1989, and 1990. Before

Received for publication 24 Oct. 1991. Accepted for publication 17 June 1992. Univ. of Florida Journal Series no. R-01569. We thank Speedling Inc., for support of this research. The cost of publishing this paper was defrayed in part by the payment of page charges. Under postal regulations, this paper therefore must be hereby marked advertisement solely to indicate this fact.

${ }^{1}$ Current address: Texas Agricultural Experiment Station, Texas A\&M Univ., 1619 Garner Field Road., Uvalde, TX 78801. sowing in trays, pepper seeds were treated for seed-borne diseases by immersion in water at 52C for 20 min (Shoemaker and Echandi, 1976), followed by a surface disinfection with $\mathrm{NaOCl}$ at $1 \%$ for $10 \mathrm{~min}$ and rinsing three times with deionized water. Priming was performed by placing the seeds in darkness in an aerated solution of polyethylene glycol (molecular weight 6000) at 0.6 MPa for 4 days at 25C (Cantliffe and Watkins, 1983). After priming, seeds were washed with running water, surface dried, and dried back to the original $6 \%$ seed moisture.

Transplant production. Overhead-irrigated transplants were grown in plastic greenhouses at Speedling, in Sun City, Fla. Speedling polystyrene trays with 200 inverted pyramid cells of $2.5 \times 7.2$ (square side length $\times$ depth; $18 \mathrm{~cm}^{3}$ volume) were used. Seeds were sown in a 2 peat : 1 vermiculite : 1 perlite mix (by volume) on several dates (Table 1). Trays were held in germination chambers at $25 \mathrm{C}$ and $100 \%$ relative humidity $(\mathrm{RH})$ for 3 days, then placed in greenhouses where they remained until transplanting. After seedling emergence, transplants were watered daily or five times a week by overhead irrigation. During each irrigation, a soluble fertilizer was applied to provide a concentration of 50,12 , and $40 \mathrm{mg} \mathrm{N}, \mathrm{P}$, and K/liter, respectively. Fertilizer and water were withheld during the last 3 days before field transplanting (for acclimation). The greenhouse was held at 24/14C maximum/minimum.

Table 1. Seeding, planting, and harvesting dates of bell pepper plants established by transplanting or direct seeding.

\begin{tabular}{|c|c|c|c|c|c|}
\hline \multirow[b]{2}{*}{ Year } & \multicolumn{3}{|c|}{ Transplanting } & \multicolumn{2}{|c|}{ Direct seeding } \\
\hline & Seeded & Planted & $\begin{array}{c}\text { Fruit } \\
\text { harvested } \\
\text { (DAT) }\end{array}$ & Seeded & $\begin{array}{c}\text { Fruit } \\
\text { Harvested } \\
\text { (DAS) }\end{array}$ \\
\hline 1988 & $1 \mathrm{Mar}$. & $10 \mathrm{Apr}$. & 72,86 , and 98 & 10 Apr. & 98 and 111 \\
\hline 1989 & $\begin{array}{l}15 \text { Feb. } \\
1 \text { Mar. }\end{array}$ & $\begin{array}{l}29 \text { Mar. } \\
10 \text { Apr. }\end{array}$ & $\begin{array}{c}78,93 \text {, and } 98 \\
98 \text { and } 113\end{array}$ & $\begin{array}{l}20 \text { Mar. } \\
24 \text { Mar. }\end{array}$ & $\begin{array}{l}102 \text { and } 107 \\
109 \text { and } 121\end{array}$ \\
\hline 1990 & $\begin{array}{l}20 \mathrm{Feb} . \\
27 \mathrm{Feb} .\end{array}$ & $\begin{array}{l}10 \mathrm{Apr} . \\
19 \mathrm{Apr} .\end{array}$ & $\begin{array}{l}78,93 \text {, and } 110 \\
68,80 \text {, and } 90\end{array}$ & $\begin{array}{l}22 \text { Mar. } \\
30 \text { Mar. }\end{array}$ & $\begin{array}{c}108 \text { and } 118 \\
110\end{array}$ \\
\hline
\end{tabular}

Abbreviations: DAP, days after planting; DAS, days after seeding; LDW, leaf dry weight; OI, overhead-irrigated; RDW, root dry weight; RGR, relative growth rate; SI, subsurface-irrigated; STDW, stem dry weight. 
Subsurfaced-irrigated transplants were grown in fully automated plastic greenhouses at Speedling, Bushnell, Fla. The trays were held in germination chambers for 3 days at $25 \mathrm{C}$ and $100 \%$ $\mathrm{RH}$, then transferred to greenhouses and suspended on metal wires $0.2 \mathrm{~m}$ above concrete floors. Every 2 days, the irrigation water was raised to the level of the container, maintained for 30 to $45 \mathrm{~min}$, then decreased to its original level until the next irrigation. Fertilizer and plant acclimation were similar to those used for the overhead-irrigated transplants. A foliar supplemental fertilizer was applied to provide a concentration of 200 and $1040 \mathrm{mg}$ of $\mathrm{N}$ and P/liter, respectively, at 25 and 35 days after seeding (DAS). The greenhouse was held at 30/16C maximum/ minimum.

Field experiments. Overhead- and subirrigated transplants and primed and nontreated seeds were planted at the Horticultural Research Unit, Gainesville, Fla., on an Arredondo fine sand (loamy, siliceous, hyperthermic, Grosarenic Paleudultus) in 1988, 1989, and 1990 (Table 1). Preplant fertilizer $\left(\mathrm{kg} \cdot \mathrm{ha}^{-1} ; 180 \mathrm{~N}-\right.$ $60 \mathrm{P}-180 \mathrm{~K}$ in 1988 and 1989 , and $136 \mathrm{~N}-42 \mathrm{P}-136 \mathrm{~K}$ in 1990) was applied broadcast and incorporated in the center of the bed. Beds were fumigated with methyl bromide : chloropicrin $(67: 33)$ at $220 \mathrm{~kg} \cdot \mathrm{ha}^{-1}$ and covered with black (1988 and 1989) or white (1990) polythylene mulch (0.038-mm thickness). In 1990, white plastic mulch was used to avoid the impact of high bed surface temperatures on young seedlings, particularly during the second transplanting on 19 Apr. (Fig. 1). Plants were grown on $0.2 \mathrm{~m}$ high raised beds at $1.8 \times 0.3 \mathrm{~m}$ (between $\times$ within rows) in 1988 and 1990 and $1.5 \times 0.3 \mathrm{~m}$ beds in 1989, using 12-mlong plots.

Plant water requirements of 25 to $40 \mathrm{~mm} \cdot$ week $^{1}$ were supplied using supplemental overhead irrigation (1988), overhead and drip irrigation (1989), or drip irrigation (1990) to keep the soil water potential above $-20 \mathrm{kPa}$ at the $0.2-\mathrm{m}$ depth. The use of drip irrigation and mulch has increased in pepper cropping systems in Florida because of several advantages, such as maintenance of nearly constant water regimes, reduction in the incidence of foliar diseases, capacity for fertilizer and chemical injection, and improvement of water conservation. Drip tubing (Netafim, Altamonte Springs, Fla.) was positioned at the soil level, $0.15 \mathrm{~m}$ to the sides of the plants. Drippers were spaced $0.60 \mathrm{~m}$ apart, with a drip discharge rate of $2.25 \mathrm{liter} \cdot \mathrm{h}^{-1}$. In 1990 , additional fertilization (8N-12P-6K) was applied weekly through the drip system for 10 weeks using $\mathrm{NH}_{4} \mathrm{NO}_{3}, \mathrm{H}_{3} \mathrm{PO}_{4}$, and $\mathrm{KNO}_{3}$ as sources of $\mathrm{N}, \mathrm{P}$, and $\mathrm{K}$, respectively. Standard pesticides and cultural practices were used (Hochmuth, 1988).

Plant samplings. In 1989, plants were sampled (two plants per replication). They were removed from the trays with forceps, and shoots were cut off at the soil-mix surface 1 week

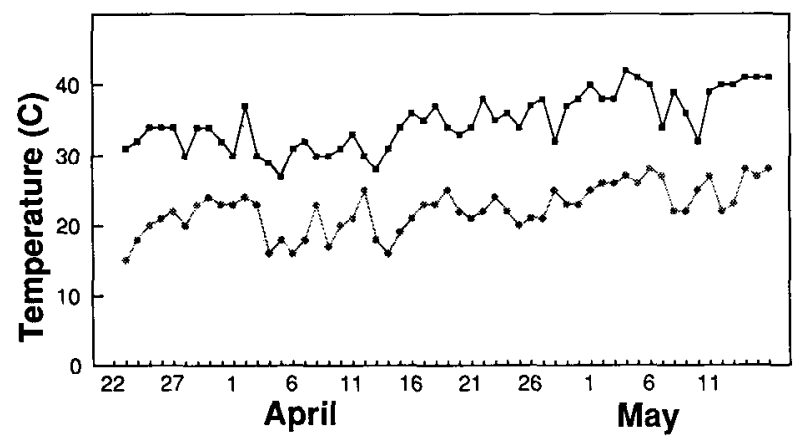

Fig. 1. Maximum and minimum soil surface temperatures during early Spring 1990. before planting $\left(\mathrm{T}_{-1}\right)$ and at planting $\left(\mathrm{T}_{0}\right)$. One week after planting $\left(\mathrm{T}_{+1}\right)$, plants were manually excavated with a shovel in an area $20 \times 20 \mathrm{~cm}$, with the plant in the center of the square, to a depth of $30 \mathrm{~cm}$. Then roots were gently washed and partitioned into basal (originating from the hypocotyl) and lateral roots (originating from the taproot). Roots were counted, and their length was measured using the modified line intercept method (Tennant, 1975) with a 1-cm grid unit. At 50, 70, and 90 days after planting (DAP), transplants and direct-seeded plants were manually excavated (one plant per replication) and partitioned into roots, stems, leaves, and fruits. Plant parts were oven dried at $65 \mathrm{C}$ for 3 to 5 days, dry weights determined, and relative growth rates (RGR) calculated.

In 1990, plant samplings were initiated 30 days after planting and continued every 2 weeks for 56 days. Roots were excavated as described by Leskovar et al. (1990a) at two soil depths, 0 to $10 \mathrm{~cm}$ and 10 to $20 \mathrm{~cm}$. On 26 July, total root mass (one plant per replication) was partitioned into three components: taproot, basal roots, and lateral roots. Roots were sampled using a metallic pinboard, consisting of a one-sided steel plate $50 \times 30$ $\mathrm{cm}$ (width $\times$ depth) and $0.5 \mathrm{~cm}$ thick, with six rows of $30-\mathrm{cm}$ long nails of $0.5-\mathrm{cm}$ diameter at $\mathrm{S}-\mathrm{cm}$ intervals. A trench of 1.0 $\times 0.5 \mathrm{~m}$ (length $\times$ depth) was dug around the plant. The soilroot samples were excavated and gently washed, roots were cut, and then separated for each component, and dry weights were determined.

Fruit yield. Fruits were harvested at the mature-green stage (20 plants per replication) on the dates indicated (Table 1). Because there were no significant differences between transplants grown with overhead- or subirrigation and between plants established with primed and nontreated seeds at each harvest, yields were pooled. Fruits were graded into U.S. Fancy (7.5$\mathrm{cm}$ minimum diameter and 8.8-cm minimum length) and U.S. No.1 (6.25-cm minimum diameter and length), counted, and weighed (U.S. Dept. of Agriculture, 1963).

Statisticalprocedures. Allometric relationships between root and shoot (leaves + stems) and between root and top (shoot + fruit) dry weights were determined (Richards, 1981) and slopes of $\ln -\ln$ regressions ( \pm confidence intervals) calculated.

During each study, a randomized complete-block design with five replications per treatment was used. Shoot growth, root growth, and fruit yield data were subjected to analysis of variance and orthogonal contrasts. Significant plant establishment $\mathrm{x}$ time interactions were partitioned for sampling date. When growth responses over time were linear, homogeneity of the regression coefficients at $P \leq 0.05$ was performed by $t$ test, $t$ $=\left(b_{1}-b_{2}\right) / \sqrt{S_{p}^{2}\left(1 / \Sigma x_{1}^{2}+1 / \Sigma x_{2}^{2}\right)}, b_{i}$ being the estimated slope, $S_{\mathrm{p}}^{2}$ the pooled residual mean square, and $\Sigma x_{1}^{2}$ and $\Sigma x_{2}^{2}$ the respective corrected sum of squares (Snedecor and Cochran, 1967).

\section{Results and Discussion}

Root development. The partitioning of significant transplant system $\times$ time interaction (Table 2) indicated that root growth of transplants grown with overhead-irrigation was increasing linearly and rapidly $(16,31$, and $51 \mathrm{mg}$ at 36,43 , and 50 DAS) compared with the quadratic root dry weight (RDW) increase of subirrigated (SI) transplants $(21,54$, and $62 \mathrm{mg})$. Overheadirrigated (OI) transplants had longer $(22 \%)$ and more basal roots than subirrigated transplants (Table 2). Overhead irrigation may provide a more-uniform moisture level around the hypocotyl, promoting early basal root growth than did subsurface irrigation. The latter system promoted more lateral root elongation. 
Table 2. Effects of transplant systems on early growth of bell pepper at 36, 43, and 50 DAS $\left(\mathrm{T}_{-1}, \mathrm{~T}_{0}\right.$, and $\left.\mathrm{T}_{+1}\right)$. First planting, 1989 .

\begin{tabular}{|c|c|c|c|c|c|c|c|}
\hline \multirow{2}{*}{$\begin{array}{l}\text { Source of } \\
\text { variation }\end{array}$} & \multirow{2}{*}{$\begin{array}{l}\text { Root dry } \\
\text { wt (mg) }\end{array}$} & \multicolumn{2}{|c|}{$\begin{array}{l}\text { Root length } \\
(\mathrm{cm}) \\
\end{array}$} & \multicolumn{2}{|c|}{ Root count } & \multicolumn{2}{|c|}{ Dry wt (mg) } \\
\hline & & Basal & Lateral & Basal & Lateral & Stem & Leaf \\
\hline \multicolumn{8}{|c|}{ Transplant system (TS) } \\
\hline Overhead & 34.0 & 362 & 254 & 32 & 15 & 66.0 & 86.9 \\
\hline \multirow[t]{2}{*}{ Subsurface } & 45.6 & 296 & 491 & 28 & 15 & 61.0 & 76.6 \\
\hline & $* *$ & $*$ & $* *$ & $*$ & NS & NS & NS \\
\hline \multicolumn{8}{|l|}{$\operatorname{Time}^{\mathbf{z}}$} \\
\hline$T_{-1}$ & 18.5 & 142 & 258 & 22 & 11 & 25.1 & 41.4 \\
\hline $\mathrm{T}_{0}^{-1}$ & 42.5 & 293 & 457 & 31 & 15 & 62.1 & 86.0 \\
\hline $\mathrm{T}_{+1}$ & 58.4 & 552 & 402 & 36 & 16 & 103.3 & 117.8 \\
\hline Significance & $\mathrm{L}^{* *}$ & $\mathrm{~L}^{* *}$ & $Q^{* *}$ & $\mathrm{~L}^{* *}$ & $\mathrm{~L}^{* *}$ & $\mathrm{~L}^{* *}$ & $\mathrm{~L}^{* *}$ \\
\hline \multicolumn{8}{|l|}{ Interaction } \\
\hline$\underline{\text { TS } \times \text { Time }}$ & $*$ & NS & NS & NS & NS & $* *$ & * \\
\hline
\end{tabular}

In 1989 under sprinkler irrigation, RDW of transplants was higher $(1.6 \mathrm{~g})$ than that of direct-seeded plants $(1.1 \mathrm{~g})$ at 50 DAP. However, between 50 and 70 DAP, direct-seeded plants had higher root RGR $\left(0.10 \mathrm{~g} \cdot \mathrm{g}^{-1} \cdot \mathrm{d}^{-1}\right)$ than transplants $(0.06)$, with more total root growth for direct-seeded (DS) plants (5.1 g) than for transplants (4.2 g). In 1989, under drip irrigation, seeded plants exhibited a greater $(5.6 \mathrm{~g})$ root mass than transplants $(4.7 \mathrm{~g})$ at 90 DAS but total root growth was similar for $\mathrm{OI}$ and SI transplants and for primed and nontreated seeded plants. As expected, the higher RDW of transplants early in development was mainly due to the initial large plant size inherent with a 6-week-old transplant and to the larger root mass associated with the early taproot modification and basal and lateral root promotion. Pepper transplants may have a time of intense basal root growth from emergence to $\approx 50$ to 70 days after planting (mid-development), the period that also coincides with the highest nutrient uptake rate and rapid fruit growth (Miller et al., 1979). Subsequently, root growth compensation is likely to occur, minimizing the initial differences in root-component dry weights.

In 1990, when plants were grown under drip irrigation, the total RDW of transplants increased linearly in the $0-$ to $10-\mathrm{cm}$ soil depth (Fig. 2A). The slope $\left(b_{1}\right)$ was $66 \%$ significantly greater $\left(56.1, r^{2}=0.93\right)$ for overhead- than for subirrigated transplants $\left(b_{2}=33.8, r^{2}=0.72\right)$. The average root growth increase for transplants was $180 \%$ higher in the upper $(0-$ to $10-\mathrm{cm})$ than in the lower $(10-$ to $20-\mathrm{cm})$ level. The lesser transplant root development in the 10 to $20 \mathrm{~cm}$ soil layer (Fig. 2B) may be associated with early taproot modification in the greenhouse, before planting (Leskovar et al., 1990a). Direct-seeded plants using primed and nontreated seeds had similar RDW in the upper soil level, with a rapid RDW increase beginning $\approx 44$ DAS (Fig. 2A). At the deeper soil level, the accumulated RDW for direct-seeded plants was uniform and with a higher rate $\left(b_{1}\right.$ $=22.6)$ of increase than for transplants $\left(b_{2}=16.0\right)$.

Basal roots accounted for the highest proportion $(81 \%)$ of the total root mass of transplants, and lateral roots accounted for the greatest proportion $(57 \%)$ of the total root mass of directseeded plants (Table 3 ). In a previous study, where pepper plants were grown in $15-\times 14-\mathrm{cm}$ (diameter $\times$ height) pots, basal and lateral roots contributed to $40 \%$ and $53 \%$, respectively, of the total RDW (Leskovar et al., 1989). Upon seeding, rapid

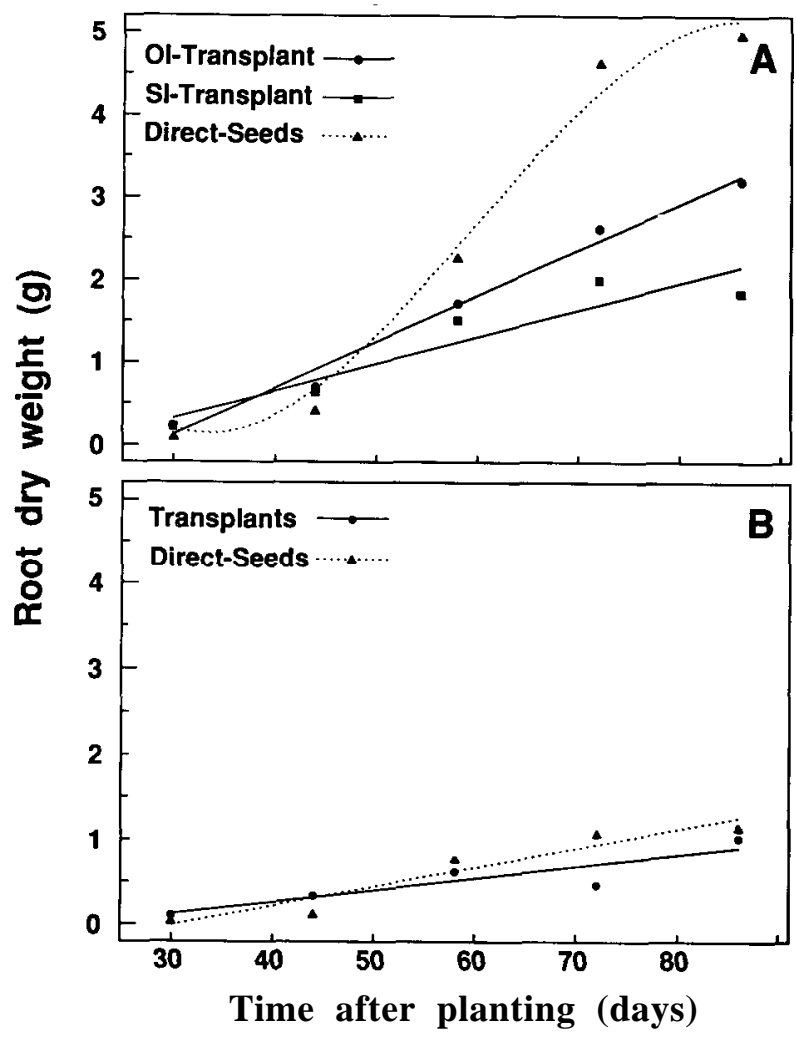

Fig. 2. Total bell pepper root dry weight from (A) 0- to $10-\mathrm{cm}$ and (B) the 10- to $20-\mathrm{cm}$ soil depths for OI transplants, SI transplants, and direct seeds in 1990.

taproot elongation occurred, and basal and lateral roots increased after a reduction in the rate of taproot elongation (Stoffella et al., 1988). Taproots accounted for only $4 \%$ of the total root mass from plants grown from transplants and $18 \%$ of seeded plants.

Shoot development. Stem dry weight (STDW) and leaf dry weight (LDW) for OI and SI transplants had a linear growth increase between 36 and 50 DAS (Table 2). Partitioning the significant transplant system $\times$ time interaction for STDW showed a higher STDW for OI transplants; for them the slope was sig- 
Table 3. Effects of plant establishment method on root components of bell pepper grown with drip irrigation (first planting, 1990).

\begin{tabular}{lcccr}
\hline \hline \multirow{2}{*}{$\begin{array}{l}\text { Plant } \\
\text { establishment }\end{array}$} & Tap & Basal & Lateral & Total \\
\cline { 2 - 5 } OI transplant & 0.32 & 6.30 & 1.31 & 7.92 \\
SI transplant & 0.38 & 8.69 & 1.32 & 10.39 \\
Primed seed & 1.98 & 1.87 & 5.71 & 9.57 \\
Nontreated seed & 2.00 & 3.49 & 6.72 & 12.20 \\
Contrasts & & & & \\
$\quad$ Transplant vs. seed & $* *$ & $* *$ & $* *$ & NS
\end{tabular}

${ }^{\mathrm{z}}$ Root samples were taken on 26 July 1990 at 106 days after transplanting.

${ }_{\text {NS, }}{ }^{* *}$ Nonsignificant or significant $\mathrm{F}$ test at $P=0.01$. OI vs. SI transplants, and primed vs. nontreated seed contrasts were nonsignificant.

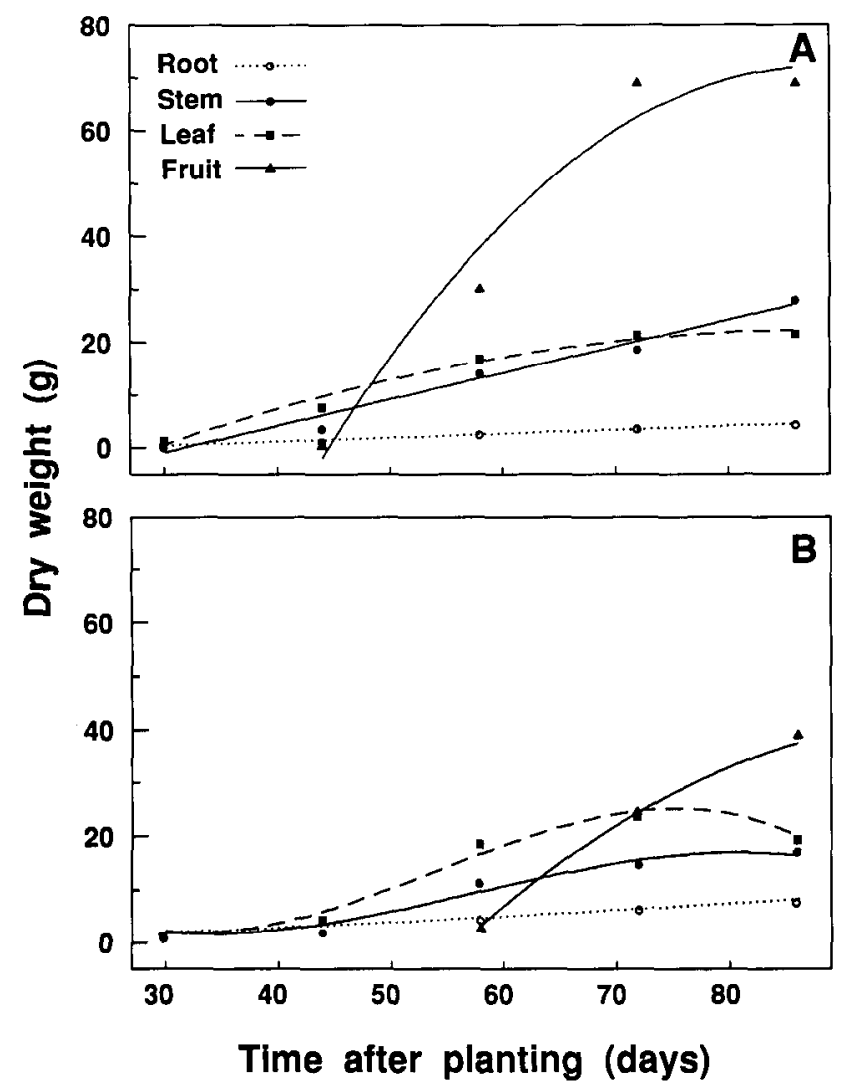

Fig. 3. Root, stem, leaf, and fruit growth for OI pepper transplants (A) and primed-seeded pepper plants (B) in 1990.

nificantly higher $(41 \%)\left(45.7, r^{2}=0.90\right)$ than the slope for STDW for SI transplants. Similarly, the LDW increase was linear and higher for OI than SI transplants; however, growth trends were similar in the field between 50 to 90 days after transplanting, either with sprinkler or drip irrigation (data not shown).

In 1990, under drip irrigation, fruit dry weight increase for overhead-irrigated transplants was evident after 50 days (Fig. 3A). Stem and root growth increase was linear over time, while leaf growth began to decline after 60 days. At the end of the growth period, fruit, stem leaf, and root dry matter were $60 \%$, $19 \%, 18 \%$, and $3 \%$ of the total, respectively for plants grown from transplants. Plants grown from primed seeds had a decline of LDW after 72 days, and STDW appeared to reach a plateau after 72 days, (Fig. 3B), while RDW increased slightly. At 86 days, fruit, stem, leaf, and root dry weight accounted for $42 \%$, $22 \%, 26 \%$, and $10 \%$ of the total, respectively, for plants grown from direct-seeded plants.

Growth coordination between shoots and roots exists when their respective logarithms (dry-weight basis) are linearly related (Richards, 1969). The lack of significant difference between $\mathrm{Kv}$ and $\mathrm{Kf}$ slopes for direct-seeded plants (Table 4) indicates that growth of roots was balanced with stems, leaves, and fruits. Conversely, the higher the $\mathrm{Kv}$ slope than the Kf slope in transplants suggests that fruits may compete more strongly with the growth of roots for nutrients and with shoots for photosynthates (decreasing Kf slopes), increasing the availability of assimilates for the developing fruits. The change in the coordination of growth between roots and shoots was previously reported for transplants grown in the field with sprinkler irrigation (Leskovar et al., 1990a). Therefore, in addition to the differential root morphological characteristics of transplants as compared with direct-seeded plants (McKee, 1981; Weaver and Bruneer, 1927), the amount of dry matter partitioning between root and shoot/ top can be altered depending on the particular planting system used.

Fruit yields. Transplants had a higher total marketable fruit yield than direct-seeded plants in 1988 (Table 5). This difference was mainly due to more No. 1 fruits, which represented $90 \%$ of the total yield. In this season, both transplanting and direct seeding were done on 10 Apr. The expected lack of earliness in yield from seeded plants was not compensated with greater later harvests.

For the 1989 first planting, OI- and SI transplants and plants from primed and nontreated seed had total, fancy, and No.1 fruit yields similar to either sprinkler or drip irrigation (data not shown). In this study, direct-seeded plants and particularly transplants were adversely affected by weather conditions, sandblasting, and severe winds that occurred immediately after planting on 29 Mar. Similar results were obtained for all treatments with the 1989 second planting, except that fancy fruit yield was higher for SI than for OI transplants and for primed than nontreated seeded plants grown with sprinkler irrigation (Table 5). The low fancy fruit yields for overhead-irrigated transplants in 1989 can be associated with the plant condition early in development. OI transplants were larger $(13.7 \pm \mathrm{SE} 0.5 \mathrm{~cm})$, with higher shoot : root ratio $(4.9 \pm 0.4)$ than SI transplants, which were smaller $(10.4 \pm 0.1 \mathrm{~cm})$ with a low shoot : root ratio $(2.9 \pm 0.3)$. Short plants with low shoot : root ratios were more tolerant to severe winds. Fruit yield differences were not measured with drip irrigation. VanDerwerken and Wilcox-Lee (1988) reported that trickle and sprinkler irrigation had minimal effect on yield of bell peppers grown with mulch culture.

In 1990 , transplants yielded $78 \%$ and $43 \%$ more fruit than direct-seeded plants in the first and second plantings, respec-

Table 4. Allometric relationship between root against shoot (leaf + stem) and root against top (shoot + fruit) dry weight (1990). ${ }^{\mathrm{Z}}$

\begin{tabular}{lcccc}
\hline \hline Treatment & $\mathrm{Kv}$ & $\boldsymbol{r}$ & $\boldsymbol{K} \boldsymbol{f}$ & $\boldsymbol{r}$ \\
\hline Direct seeds & $0.563( \pm 0.053)$ & 0.944 & $0.492( \pm 0.029)$ & 0.978 \\
Transplants & $0.441( \pm 0.052)$ & 0.915 & $0.322( \pm 0.033)$ & 0.936 \\
\hline
\end{tabular}

${ }^{\mathrm{z}}$ Linear regressions are in the form $\ln$ (root dry $w \mathrm{t}$ ) $=\mathrm{a}+\mathrm{Kv} \times \ln$ (shoot dry weight) or In (root dry weight) $=\mathrm{a}+\mathrm{Kf} \times \ln$ (top dry weight), where $\mathrm{Kv}$ and $\mathrm{Kf}( \pm 95 \%$ confidence limits $)$ are the slopes and $r$ is the regression coefficient $(P \leq 0.05)$. Dry weights of primed and nontreated seeded plants (direct seeds) and OI and SI transplants were pooled. 
Table 5. Effects of bell pepper plant establishment methods on fruit yield and number per plant (1988, 1989, and 1990 early and late plantings). ${ }^{\mathrm{z}}$

\begin{tabular}{|c|c|c|c|c|c|c|c|c|c|c|c|c|}
\hline \multirow{2}{*}{$\begin{array}{l}\text { Plant } \\
\text { establishment }\end{array}$} & \multicolumn{3}{|c|}{1988} & \multicolumn{3}{|c|}{$1989^{y}$} & \multicolumn{3}{|c|}{1990 Early planting } & \multicolumn{3}{|c|}{1990 Late planting } \\
\hline & Fancy & No. 1 & Total & Fancy & No. 1 & Total & Fancy & No. 1 & Total & Fancy & No. 1 & Total \\
\hline & \multicolumn{12}{|c|}{ Yield $\left(t \cdot h a^{-1}\right)$} \\
\hline OI transplant & 2.8 & 21.9 & 24.7 & 2.3 & 14.1 & 16.4 & 0.5 & 19.7 & 20.1 & 1.4 & 14.5 & 15.9 \\
\hline SI transplant & 2.5 & 22.1 & 24.6 & 4.9 & 14.2 & 19.1 & 2.1 & 22.7 & 24.9 & 1.1 & 14.4 & 15.5 \\
\hline Primed seed & 0.1 & 9.4 & 9.5 & 4.7 & 13.1 & 17.7 & 0.0 & 12.0 & 12.0 & 0.0 & 11.5 & 11.5 \\
\hline Nontreated seed & 0.0 & 8.4 & 8.4 & 2.3 & 11.1 & 13.4 & 0.0 & 13.1 & 13.1 & 0.0 & 10.5 & 10.5 \\
\hline \multicolumn{13}{|l|}{ Contrasts } \\
\hline Transplant vs. seed & $* *$ & $* *$ & $* *$ & NS & NS & NS & $* *$ & ** & $* *$ & $* *$ & $* *$ & $* *$ \\
\hline OI vs. SI transplant & NS & NS & NS & * & NS & NS & $* *$ & NS & $*$ & NS & NS & NS \\
\hline \multirow[t]{2}{*}{ Primed vs. nontreated } & NS & NS & NS & $*$ & NS & $*$ & NS & NS & NS & NS & NS & NS \\
\hline & \multicolumn{12}{|c|}{ Fruit/plant } \\
\hline OI transplant & 0.6 & 6.9 & 7.5 & 0.5 & 4.5 & $5.0^{\circ}$ & 0.1 & 8.5 & 8.6 & 0.3 & 6.2 & 6.5 \\
\hline SI transplant & 0.5 & 6.9 & 7.4 & 1.1 & 4.4 & 5.5 & 0.5 & 8.5 & 9.0 & 0.2 & 6.4 & 6.6 \\
\hline Primed seed & 0.1 & 3.8 & 3.8 & 0.9 & 4.5 & 5.4 & 0.0 & 6.5 & 6.5 & 0.0 & 5.1 & 5.1 \\
\hline Nontreated seed & 0.0 & 3.7 & 3.7 & 0.4 & 4.1 & 4.5 & 0.0 & 6.8 & 6.8 & 0.0 & 5.0 & 5.0 \\
\hline \multicolumn{13}{|l|}{ Contrasts } \\
\hline Transplant vs. seed & $* *$ & $* *$ & $* *$ & NS & NS & NS & $* *$ & $* *$ & $* *$ & $* *$ & $* *$ & $* *$ \\
\hline OI vs. SI transplant & NS & NS & NS & $* *$ & NS & NS & $* *$ & NS & NS & NS & NS & NS \\
\hline Primed vs. nontreated & NS & NS & NS & $*$ & NS & NS & NS & NS & NS & NS & NS & NS \\
\hline
\end{tabular}

${ }^{\mathrm{z}}$ Minimum fruit diameters were $7.5 \mathrm{~cm}$ (fancy) and $6.2 \mathrm{~cm}$ (No. 1).

${ }^{\mathrm{y}}$ Second planting under sprinkler irrigation.

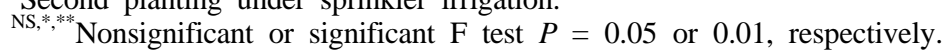

tively (Table 5). Within a transplant group, the only yield difference between transplants occurred during early planting, with SI plants having $24 \%$ higher total yield and more fancy fruits than OI transplants. As previously indicated, this response could be associated with the superior condition of SI transplants at planting, lower shoot : root ratio (4.9 vs. 6.4), and higher total RDW (35 vs. $24 \mathrm{mg}$ ), basal RDW (21 vs. $16 \mathrm{mg}$ ), and lateral RDW (15 vs. $9 \mathrm{mg}$ ) than for OI transplants. The importance of early root growth and shoot : root ratios on subsequent growth and yield has also been emphasized in tomato (Lycopersicon esculentum Mill.) transplants before planting (Leskovar et al., 1990b).

Growth and development in the field are closely related to plant size, plant morphology, physiological age of the seedlings at planting, and field environmental conditions throughout development. In this study, the increase in fruit production for pepper transplants may not solely be related to the initial large plant size that significantly advanced plant maturity but also due to the improved root and shoot growth and superior fruit set and fruiting efficiency as compared with direct-seeded plants during spring. Maximum fruit set for bell peppers occurs between 16 and $21 \mathrm{C}$ and is strongly inhibited $>32 \mathrm{C}$. During late spring, high temperatures during the generative stage also may have limited the yield potential of direct-seeded plants. To avoid high temperatures during late spring, direct-seeding might be done during early March, in Florida; however, this may increase the risk of frost damage. In tomatoes, it has been reported that fieldseeded plants had lower early but similar total yields as transplants when grown on a clay soil in early spring (Liptay et al., 1982) and similar early and total yields when grown on a sandy soil covered with black mulch in spring (Long and Cantliffe, 1975). Therefore, for spring plantings, fruit yield compensation for the lack of earliness (compared with transplants) appears to be lower for direct-seeded bell peppers than for direct-seeded fresh-market tomatoes during later harvests.

In conclusion, planting methods influenced dry-matter parti- tioning throughout growth and development of bell pepper in the field. Transplants that had constant but lower total root growth than direct-seeded pepper plants produced earlier and higher fruit yields than plants established by direct seeding with either primed or nontreated seeds in 1988 and 1990.

\section{Literature Cited}

Cantliffe, D.J. and J.T. Watkins. 1983. More rapid germination of pepper seeds after seed treatment. Proc. Fla. Hort. Soc. 96:99-101.

Heydecker, W. and P. Coolbear. 1977. Seed treatments for improved performance-survey and attempted prognosis. Seed Sci. Technol. 5:353-425.

Hochmuth, G.J. (ed.). 1988. Pepper production guide for Florida. Fla. Coop. Ext. Serv., IFAS, Univ. of Florida Circular 102 E, Gainesville.

Leskovar, D.I., D.J. Cantliffe, and P.J. Stoffella. 1990a. Root growth and root-shoot interaction in transplants and direct seeded pepper plants. Environ. Expt. Bot. 30:349-354.

Leskovar, D.I., D.J. Cantliffe, and P.J. Stoffella. 1990b. Early transplant growth in relation to fruit yield in tomato. HortScience 25:140.

Leskovar, D.I., P.J. Stoffella, and D.J. Cantliffe. 1989. Pepper (Capsicum annuum L.) root growth and its relation to shoot growth in response to nitrogen. J. Hort. Sci. 64:711-716.

Liptay, A., E.F. Bolton, and V.A. Dirks. 1982. A comparison of fieldseeded and transplanted tomatoes grown on a clay soil. Can. J. Plant Sci. 62:483-487.

Long, D.G. and D.J. Cantliffe. 1975. Response of fresh market tomatoes to method of seeding or transplanting. Fla. State Hort. Soc. Proc. 88:211-213.

McKee, J.M.T. 1981. Physiological aspects of transplanting vegetables and other crops. I. Factors which influence re-establishment. Hort. Abstr. 51:265-272.

Miller, C.H., R.E. McCollum, and S. Claimon. 1979. Relationship between growth of bell peppers (Capsicum annuum L.) and nutrient accumulation during ontogeny in field environments. J. Amer. Soc. Hort. Sci. 104:852-857.

Richards. F.J. 1969. The quantitative analysis of growth, p. 3-76. In: F. Stewart (ed.). Plant physiology, analysis of growth: Behaviour of plants and their organs. Academic, New York. 
Richards, D. 1981. Root-shoot interactions in fruiting tomato plants, p. 373-380. In: R. Brower, O. Gasparikova, J. Kolek, and B.C. Loughman (eds.). Structure and function of plant roots. vol. 4. Nihoff-Junk, The Hague, Netherlands.

Shoemaker, P.B. and E. Echandi. 1976. Seed and plant bed treatments for bacterial canker of tomato. Plant Dis. Rptr. 60:163-166.

Snedecor, G.W. and W.G. Cochran. 1967. Statistical methods. Iowa State Univ. Press. Ames.

Stoffella P.J., M.L. Di Paola, A. Pardossi, and F. Tognoni. 1988. Root morphology and development of bell peppers. HortScience 23:1074-1077.

Tennant, D. 1975. A test of modified line intersect method estimating root length. J. Ecol. 63:995-1001.
Thomas, T.H., A. Barnes, and C.C. Hole. 1982. Modification of plant relationships in vegetable crops, p. 297-311. In: J.S. McLaren (ed.). Chemical manipulation of crop growth and development. Butterworth Scientific, London.

U.S. Department of Agriculture. 1963. United States standards for grades of sweet peppers. U.S. Dept. Agr./Agr. Mktg. Serv., Washington D.C.

VanDerwerken, J.E. and D. Wilcox-Lee. 1988. Influence of plastic mulch and type and frequency of irrigation on growth and yield of bell pepper, HortScience 23:985-988.

Weaver, J.E. and W.E. Bruner. 1927. Root development of vegetable crops. McGraw-Hill, New York. 